
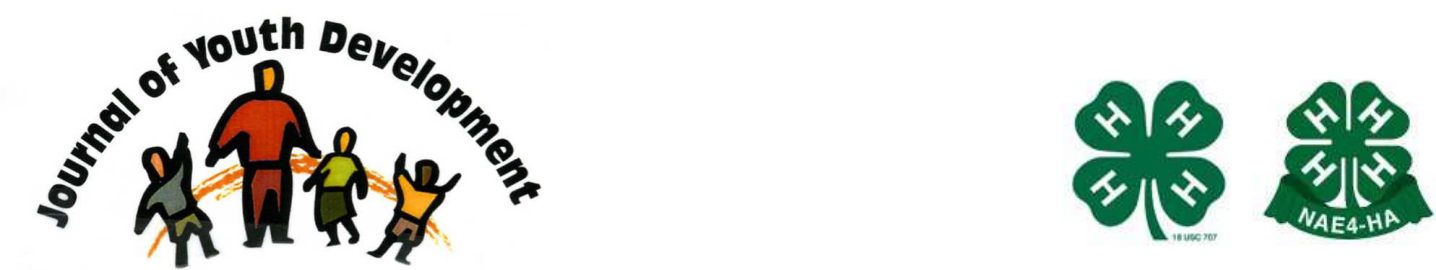

Bridging Research \& Practice

\title{
Patterns of Success for Urban 4-H Youth Development in the Near Future
}

\author{
W. Jack Kerrigan, Jr.
}

Ohio State University Extension

Wooster, $\mathrm{OH}$

kerrigan.1@osu.edu 


\title{
JOURNAL OF YOUTH DEVELOPMENT \\ bridging research and practice
}

\section{Patterns of Success for Urban 4-H Youth Development in the Near Future}

\author{
W. Jack Kerrigan, Jr. \\ Ohio State University Extension
}

\begin{abstract}
A Modified Delphi study identified patterns of success for urban Extension 4-H programming in the next five years. The Delphi panel of 20 experts represented all regions, program areas, organizational levels as well as two external friends of Extension. The Delphi process provided both quantitative and qualitative data on the topics of collaboration, target populations, and programming. Fifteen patterns of success were identified for urban $4-\mathrm{H}$ youth development. These patterns should serve as best practices for Extension youth development programming in urban counties for "making the best better!" in the near future.
\end{abstract}

\section{Introduction}

"As the United States has grown, and metropolitan areas have become the home for the majority of the population, Cooperative Extension has 'followed the people' by developing programs that address the specific educational needs of the urban residents." (Urban Task Force, 2003). Urban 4-H youth development and its collaborating youth-serving organizations strive to:

- teach life skills,

- cultivate leadership,

- teach healthy life styles,

- improve academic achievement,

- facilitate meaningful relationships with adults and other youth, and

- provide authentic service learning opportunities.

When the Smith-Lever Act of 1914 was enacted, more than 50 percent of the United States' population lived in rural areas, and 30 percent of the workforce was engaged in farming. Today 
fewer than two percent of Americans farm for a living and only 10 percent of Americans live in rural areas according to a report in 2002 by the National Association of State Universities and Land-Grant Colleges. The issue, however, is not the tension between rural and urban Extension focus, but how Extension can best serve the urban centers of America and demonstrate its value in order to continue receiving support from public funds (Committee on the Future of the Colleges of Agriculture in the Land Grant University System, National Research Council, Board on Agriculture, 1996).

Ahearn, et al, (2003) report significant shifts in national funding patterns for Extension with the Federal partner providing only 24 percent compared to 47 percent from state support, and 27 percent from local funds in 2000. The local portion reported includes 6.6 percent from non-tax dollars, including grants, contracts and gifts. With a considerable portion of the Extension budget coming from the state partner, and the increasing influence of urban and suburban legislators in the funding decisions for Extension, it is imperative that Extension programs and information are effectively marketed to urban and suburban residents, community leaders, and elected officials.

While resources, both financial and human, are decreasing, urban Extension is faced with the challenges of programming for an increasingly complex and critical array of social and economic problems. At the same time, public funding sources are requiring greater accountability and documentation of program impact. There is a dearth of data on benchmarks for quality to guide urban Extension professionals in decisions concerning urban programming (Crosby, \& Hamernik, 2002). These authors recommend, "Inquiry that would result in a description of a quality urban Extension program would serve as a guide for urban Extension staff, providing benchmarks that indicate a quality program."

Patterns of success provide research-based guidance to urban Extension. With this information, Extension administration can examine funding and staffing needs in urban offices and is better able to establish realistic program focus and impact expectations. An increased understanding of the resources needed for successful urban Extension programs allows realistic discussions to build the resources and relationships needed to achieve higher levels of success. Successful communication of impacts and consistent practice of key urban Extension patterns of success should lead to an Extension Service that is seen as a vital societal institution.

\section{Purpose}

A study was conducted to describe the patterns of success of a high-impact urban Extension county program from 2005 through 2010. This article is focused on the findings related to urban Extension's youth development programming. No attempt was made to determine specific metrics for benchmarking youth development programs, rather, general best practices or patterns of success were identified.

\section{Research Methods}

A Modified Delphi technique using three rounds of input from a panel of twenty experts was used. The statements in the Delphi questionnaire were based on a case study of a successful and respected urban Extension office, and an extensive literature review. The case study site was Penn State Cooperative Extension in Allegheny County. It was identified through a 
nomination process by Directors of Extension. In each of the three rounds of the modified Delphi process, panelists were asked to rate each statement as a practice for the future in urban Extension offices using a 6-point Likert-type scale (strongly disagree $=1$, disagree $=2$, mildly disagree $=3$, mildly agree $=4$, agree $=5$, and strongly agree $=6$ ). Panelists were allowed to justify their response with written comments and suggest changes to the statement. The consensus level was set at 80 percent for this study. When 80 percent of the responses fell within two adjacent categories on the 6-point Likert-type scale, consensus was reached on the statement and the statement was removed from the succeeding round/s. Two levels of importance were recognized for this study based on the mean score on the 6-point Likert-type scale. Statements for which consensus was reached and with a mean score of greater than or equal to 5.0 were considered vital practices and those with a mean score between 4.25 and 4.9 were important practices. Each of the rounds was conducted using Zoomerang (2002), an Internet-based service for business and individual surveys. Qualitative data were analyzed using QSR NUD•IST (1997).

Extension Directors nominated the panel members. Individuals were identified as experts based on meeting two or more of the following criteria:

- a high level of knowledge and experience in urban Extension education;

- experience in urban informal adult education or youth development;

- experience in administering urban extension programs at either the county, district, state, or national level; and

- experience in research or scholarly work in the area of informal adult education or youth development.

The panel of experts is critical to the veracity of the Delphi process. Scheele (1975) recommends three categories of panelists.

1. Expert - people who are seen as holding the necessary knowledge and experience to provide quality information. This category included an Extension state director and Extension associate directors from states with significant urban populations, urban specialists, program leaders working primarily in urban programming, urban county chairs/directors, and urban county agents/educators doing the programming. These panelists were selected based on reputation and the recommendation by their peers and state Extension directors.

2. Stakeholders - people who will be affected by decisions made by the panel. This category included urban county chairs/directors, urban agents/educators doing the programming, and core funders.

3. Facilitators - people who have process skills that will assist the Delphi by clarifying, categorizing, synthesizing and facilitating the communication process as a participant. These people are ones listed above and chosen based on both their urban programming expertise and their facilitation skills.

The Panel of 20 experts demographics:

- Representation at various levels of Extension:

- National level Extension personnel - 2

- State and/or district level Extension personnel - 5

- County Directors - 4 
- County Extension Educators/Agents - 5

- Youth development specialist - 1

- Adult education specialist - 1

- Stakeholders - 2

- Gender:

- Females -12

- Males -8

- Race:
- Caucasian - 16
- African-American - 4

- Regional distribution:
- West - 2
- South -6
- North Central - 7
- North East - 5

The Institution Review Board of The Ohio State University approved the Modified Delphi instrument and the case study protocols.

\section{Findings and Discussion}

Consensus was reached on 15 of 18 statements in the Delphi instrument. The statements were organized into three categories: 1. Collaboration, 2. Target populations, and 3. Program delivery. The number in parenthesis is the mean score on the 6-point Likert-type scale and indicates the level of agreement.

1. Collaborating with other youth-serving organizations:

- Partners with other youth-serving organizations. (5.47)

- Staff trains staff of other youth-serving organizations in positive youth development. (5.26)

- Shares 4-H program materials with staff of other youth-serving organizations. (4.79)

2. Target populations:

- Provides out-of-school time programs. (5.35)

- Provides prevention programs for youth-at-risk. (5.11)

- Works with a wide diversity of youth, including those of different races, ethnicities, sexual orientations, and physical and mental abilities. (5.00)

- Targets urban youth who often have multiple risk factors. (4.70)

- Provides enrichment programs during school. (4.58)

- Effectively programs with both urban and suburban youth. (4.50)

3. Program delivery:

- Programs are provided by persons (paid staff or volunteers) with whom the youth involved can identify because of common characteristics such as interests, culture, racial/ethnic background, gender, or sexual orientation. (5.26)

- Programming includes exploring careers. (4.95) 
- Uses authentic civic involvement to provide a setting for developing skills, such as writing, public speaking, networking, collaborating, teamwork and leadership. (4.65)

- Uses service learning as an authentic way of connecting youth to their community through interdisciplinary, collaborative, engaged learning. (4.65)

- Provides opportunities for youth to experience mentoring or apprenticeships to enhance technical, personal, and social competencies. (4.58)

- Gives youth, especially teenagers, a significant voice in the programs offered. (4.55)

\section{Collaborating With Other Youth-Serving Organizations}

The Delphi panelists strongly agreed on the importance of 4-H/youth development collaborating with other youth-serving organizations. Collaborations with organizations such as Boys and Girls Clubs, YMCA, YWCA, libraries, community/neighborhood agencies, and faith-based organizations maximizes resources and impacts. By 4-H bringing its research-based programs and staff training to these organizations, the capacity to better serve urban youth is enhanced.

Ferrari and Sweeney's "club-within-a-club" model (2005) of collaboration offers opportunities for both urban 4-H and urban youth development organizations. This model provides 4-H educators easy access to urban youth while expanding the type of programming available to other youth development organizations. The African concept of the village raising children is affirmed in the model of Bronfenbrenner (1994) in which all segments of society form a web of information sharing about each child's development, and there is community-wide agreement on the standards of behavior.

The groundbreaking research of Blyth and Roehlkepartain reported in 1993 demonstrated the impact of communities, both assets and problems, on the development of youth within the community. Their research identified the following behaviors as "at-risk": tobacco, alcohol and illicit drug use, sexual activity, depression/suicide, anti-social behavior, and school problems. Blyth and Roehlkepartain (1993, pg. 58) had these recommendations for youth-serving organizations, such as 4-H:

- Cooperate rather than compete. Redefine goals in terms of community needs rather than organizational needs.

- Avoid underselling the value of their efforts on behalf of youth.

- Establish consensus within the community on when and where activities and programs can operate with the least conflict.

- Work to increase the diversity of youth involved and the number of opportunities per youth that are available in the community.

- Cooperate with schools and other organizations to gather information on all opportunities available for youth in the community.

- Work actively with the families of the youth to encourage their support of the schools and other organizations that work with young people.

- Support school levies and other needed school policy issues that benefit youth.

- Provide activities for all types of youth.

Extension's research-based programs, many of which are skill development-based, are assets. $4-\mathrm{H}$ 's use of the principles of positive youth development is particularly valuable. There is strong 
evidence for and agreement on the effectiveness of positive youth development (Connell, Gambone, \& Smith, 2001; Connell, \& Kubisch, 2001; Damon, 2004; Dierking, \& Falk, 2003; Eldredge, Piha, \& Levin, 2002; Hamilton, \& Hamilton, 2004; Huebner, 2003; MacDonald, \& Valdivieso, 2001; Pace, 2003; Perkins, \& Borden 2003; Steinberg, Almeida, \& Allen, 2003). By training youth development staff and volunteers of other organizations, 4-H builds the capacity of the community to better serve youth.

Csikszentmihalyi and Schneider (2000) see the need for high levels of challenge and skill development to prepare adolescents for the roles of adulthood. Youth development programs that enhance "life satisfaction and positive affect" have been demonstrated to "buffer against the negative effects of stressful life events" according to Park (2004, pg. 35). 4-H projects and activities challenge youth to greater skill development and build leadership and citizenship capacity.

\section{Target Populations}

In urban centers, the stresses of a neighborhood can be difficult for youth and adults alike. There is great concern for America's youth. This concern has given rise to terms such as "youth-at-risk." Urban 4-H must focus its efforts to address the challenges faced by urban and suburban youth-at-risk. Difficult choices must be made when human and fiscal resources are limited. Out-of-school time was identified as an important arena for 4- $\mathrm{H}$.

\section{Out of School Time Programs:}

Out-of-school time programs are increasing, as more working parents need childcare for younger children and supervised activities for older children. The Future of Children Report (2000) states that nearly three-fourths of all youth ages six to seventeen have mothers who work. Out-of-school programs fall into three categories: school-age childcare, academic enrichment programs, and youth development. These programs are normally provided by schools, community and faith-based organizations, community schools, and child care providers (Eilertson, et al., 2003).

Participation in voluntary, structured activities during out-of-school time "is associated with development of positive identity, increased initiative, and positive relationships with diverse peers and adults, better school achievement, reduced rates of dropping out of school, reduced delinquency, and more positive outcomes in adulthood" (Barber, Eccles, \& Stone, 2001). 4-H can provide a connection between out-of-school time care providers and schools because of its relationships with schools, community organizations, faith-based organizations, and childcare providers. However, the organizations that provide these services are challenged in finding qualified staff to work with the children and youth. These staff positions are traditionally poorly paid; a situation that results in poorly qualified staff. This situation offers 4-H an opportunity to train those who provide services in positive youth development as well as in the use of $4-\mathrm{H}$ program materials. In cities where a citywide coalition of agencies works together in providing out-of-school programs (Noam, Miller, \& Barry, 2002), 4-H has the potential to accept an active role in the coalition, building relationships with agencies throughout the city.

\section{School Enrichment:}

Although identified as a lower, but important priority, school enrichment programs should be a part of urban 4-H outreach if possible. Schools are partnering with agencies, businesses, and organizations to address a multitude of issues facing children. The connection between the in- 
school and out-of-school learning is seen as an opportunity to interconnect and align the learning in both spheres so that youth get a coherent, consistent message (Irby, Pittman, \& Tolman, 2003). Noam (2003) cautions that the bridging between in-school and out-of-school programs does not mean that out-of-school programs should become school-like, but rather that the goals and objectives be consistent.

Urban 4-H continues to address educational issues by "encouraging young people to develop inquiring minds, an eagerness to learn, and the ability to apply science and technology, to learn practical skills and acquire knowledge, to maintain optimum physical and mental health, and to increase leadership capabilities" (Rasmussen, 1989). 4-H is an active partner with urban school districts in improving scientific literacy and reading skills.

\section{Minority Youth:}

Although youth from all segments of American society face serious challenges, the challenges are acute for low-income, minority youth. Olive (2003) suggests that for African-American youth, the disarray of the family, the survival needs of the family, and the multiple transitions the youth often face are factors of the increasing level of risk. Specifically involving youth in high-risk environments, Hobbs (1999) recommended 4-H agents collaborate with communitybased, youth-serving organizations by providing in-service training for staff of schools and community-based organizations, facilitating cooperative programming, and helping community leaders understand the importance of youth development programs.

\section{Suburban Youth:}

It is inappropriate to think that youth at risk are only urban poor. Youth-at-risk is a term that is not socio-economically bound. The Children's Defense Fund (2000) refers to "affluenza-the poverty of having too much that is worth too little" and it afflicts youth from all socioeconomic strata. The Committee on Community-level Programs for Youth, National Research Council and Institute of Medicine (2002) reported its belief that 25 percent of American youth are seriously at risk of not being able to become productive adults in today's society. This study indicated a need to work with both inner-city and suburban youth.

\section{Technology:}

With limited financial and human resources, 4-H youth development educators are faced with deciding which populations of youth should be targeted. Striking a balance between the extensive needs of inner-city youth and youth in the suburbs where there may be more youth development programs is challenging. Providing Internet-based $4-\mathrm{H}$ programs and materials may provide access for more affluent youth with easy access to computers while allowing staff and volunteers more time to work directly with inner-city teachers and youth development providers.

\section{Program Delivery \\ Environment:}

The environment in which a young person grows up has profound impacts on that young person's development in society (Avenilla, \& Singley, 2001). It is therefore clear that youth development must take into account the environmental context in which youth are living. Individuals working with urban youth should understand the urban environment and its stress factors. Additionally youth development professionals and volunteers must have the knowledge 
and skills to work with youth as well as appropriate personal characteristics and beliefs according to Yohalem (2003).

Of key importance notes Yohalem (2003) is the ability to establish meaningful relationships with the youth involved as well as their families. She also states the importance of knowing and understanding relevant educational, social, and ecological theories affecting youth development. An example of an important personal characteristic is that of autonomy verses control in 4-H adult leaders. This characteristic has been shown to impact the level of achievement by youth in life skills and non-cognitive skills development (Astroth, 2005).

Greater ethnic diversity is a hallmark of urban centers. An understanding of the complexities of the urban socio-cultural environment is essential to an understanding of each youth's development according to Ecological Systems theory (Bronfenbrenner, 1989; Schiamberg, Paulson, \& Zawacki, 1998).

\section{Ethnicity:}

When working with urban Native American youth the inseparable connection between the urban Native American community or extended family, and the Native American culture must be understood and acknowledged according to Cheshire and Kawamoto (2003). Latino youth are diverse populations that differ based on the socioeconomic factors and the country from which their families immigrated. Spanish-speaking staff is not necessarily a benefit when working with Latino youth, but it is not a hindrance either (Rodriguez, et al., 2003). Issues of family and gender roles are important when interacting with Latinos.

\section{Gender, Sexuality, and Ability:}

Gender is a natural component in how youth interact and learn. Adult leaders must understand these gender issues especially when working with Latino youth where the culture emphasizes male and female social roles (Denner, \& Griffin, 2003). Adult leaders' comfort with youth sexuality issues impact quality of interactions with youth (Russell, \& Andrews, 2003). Youth with physical and mental disabilities come from all segments of society, however, these youth may need specially trained adults who understand how to modify programs for pace and adapted milestones in achievement (Onaga, Carolan, Maddalena, \& Villarruel, 2003).

Youth development programs cannot avoid or shy away from such difficult issues as physical and mental disabilities or the taboo issues of sexual orientation (Delgado, 2002). Delgado stresses the need for authentic integration of youth into the fabric of the community through meaningful service activities and including youth in community organizations so that they may see successful adults and learn societal norms of interaction. Additionally, working with targeted minority groups as a separate population also may serve as a "safe haven" for youth development (Johnston-Nicholson, Collins, \& Holmer, 2004).

\section{Career Exploration:}

Engagement in the community is a step toward the preparation of youth to join in the social fabric of the workplace. Exploring careers expands a youth's world as well as expanding that youth's understanding of self. Ferrari (2003) recommends that career exploration and development programs closely align with the principles of positive youth development and sound educational theory. Career programs should be intentional and developmentally appropriate, include active involvement in exploration of a wide variety of options, be focused 
on skill development and positive role models, be of adequate duration, frequency and intensity, and be led by adults with adequate training for working with youth (Ferrari, 2003). Interpersonal and communication skills that are needed in everyday life and on the job should be intentional outcomes of job readiness (Committee on Community-level Programs for Youth, National Research Council and Institute of Medicine, 2002).

\section{Experiential Learning:}

Ferrari (2003) also emphasizes experiential learning in authentic situations. Apprenticeship type experiences can fit this model and provide technical, personal, and social competence (Hamilton, \& Hamilton, 2004). Mentoring has proven to be a successful method to enhance youth development in and outside of career training programs. One example of an effective mentoring program outside of career education was in mentoring Latino immigrant youth as they transitioned into American culture (Roffman, et al., 2003).

\section{Service Learning and Civic Engagement:}

Service learning is seen as a potentially and hopefully authentic, place-based way of connecting youth to their community. Blank, Johnson, and Shah, (2003, pgs. 115-116) see this "environment integrating" service learning as "a framework for interdisciplinary, collaborative, student-centered, hands-on, and engaged learning." Community involvement helps to integrate youth into the community while building capacity and exposure to civic involvement.

Youth organizations are a positive format for this civic engagement because, unlike schools and family settings, the youth interact as equals within the group, free from the institutional hierarchy of adults providing leadership. In the experience of youth organizations involved in civic projects, "youth can learn how members of a group can disagree, debate, negotiate differences, and ultimately reach a group decision" (Flanagan, \& Van Horn, 2003, pg. 283).

Civic involvement helps youth understand the environment and culture of their community as exemplified in the "service to my community" part of the 4-H pledge. Authentic civic involvement provides a setting for developing skills such as writing, public speaking, networking, and collaborating (Sherman, 2002). Not only does civic involvement benefit youth, it benefits the community (Pancer, et al., 2002). Additionally, it is important that youth be treated as partners in community development when included in these projects (Perkins, et al., 2003).

\section{Asset Development:}

A newer concept that is more positive in approach is focused on asset development, a more positive human development context that serves "to protect from, or inhibit, healthcompromising behavior and enhance the opportunity for positive developmental outcomes" according to Benson, (2002, pg. 125). Included in the assets approach is character education, which can include such approaches as service learning, social-emotional learning, and prevention programs (Berkowitz, \& Bier, 2004).

\section{Self-determination:}

Self-determination by youth, especially older youth, is critical in empowering youth for future decision-making (Kirshner, O'Donoghue, \& McLaughlin, 2002). As youth serving organizations continue their work and decide how to allocate finite resources, these organizations should include youth in all decisions (Ream, \& Witt, 2004). Allowing youth, especially teenagers, a 
significant voice in these programs could increase participation rates of older youth (The Future of Children Report, 2000). Relevancy also is an issue with Wynn (2003) suggesting that programs related to career options, job training, job mentoring, and apprenticeships should have great appeal.

4-H is described as "a community of young people across America who are learning leadership, citizenship, and life skills" (National 4-H Council, 2004). This study strongly confirms this conceptualization of $4-\mathrm{H}$ youth development.

\section{Conclusions and Implications}

This study identified a set of "patterns of success" or approaches for successful 4-H/youth development programming in urban counties specifically for 2005 through 2010. Extension professionals' efforts to maximize these patterns of success should result in increased positive impact on youth in America's urban counties.

\section{Collaboration}

Collaboration with youth-serving organizations is essential for urban 4-H youth development programming. Collaborations can build consistency between in-school and out-of-school learning and development. Together with the collaborators, urban 4-H should establish a community wide network of support to address a wide range of youth issues. This effort must include methods that engage parents and caregivers. To strengthen the capacity of all organizations in these networks, urban 4-H staff should train paid and volunteer staff in the theory and practice of positive youth development. Extension's research-based curriculum materials should be shared with collaborators.

\section{Target populations}

There is a compelling need for urban 4-H to address a wide diversity of youth including those with high risk factors. This requires that $4-\mathrm{H}$ professionals and staff continue to enhance their understanding of all cultures in urban areas, including ethnic, racial, and socio-economic cultures. Ideally both paid and volunteer staff will increasingly reflect the diversity of the youth they serve. Urban Extension is an obvious place for the Extension organization to increase the diversity of its staff, although Ingham (2005) sees this as a need throughout the organization.

Adults who work with urban youth must understand the urban environment and its stress factors that affect youth and their families. Understanding or having the same background of the youth makes working within the racial, ethnic, and cultural setting more natural. A combination of knowledge, skills, and personal characteristics and beliefs are needed to positively affect urban youth. Specific skills may be required when working with youth with emotional or physical special needs. Collaborations with organizations that target specific populations of youth can maximize program effectiveness and allow staff of both organizations to learn from each other.

\section{Program Delivery}

The use of authentic experiences in the youths' community is powerful and connects youth to their community. These experiences should focus on technical, personal and social skill development. These skills will enhance achievement in school, on the job, and in the community. Using Extension's research-based curricula ensures quality in programming. Self- 
determination, especially with older youth, develops decision-making skills while motivating continuing involvement in youth development programs.

\section{Recommendations for Extension}

- Hire staff that are experts in positive youth development and enhance their skills and enhance their ability and commitment to train other professionals and volunteers in these principals.

- Hire staff that are comfortable and effective in working with youth and adult leaders from diverse backgrounds and provide ongoing training to cultivate both attitudes and skills.

- Select paid staff and volunteers with whom the youth involved can identify because of common characteristics.

- Enhance the collaborative skills in paid and volunteer staff and reward behaviors that result in successful collaborations.

- Establish policies that make collaborating easy.

- Maximize out-of-school programming and continue in-school programs based on local needs.

- Maximize the use of authentic experiences to enhance life skills and social development.

- Involve youth and potential youth in program development, delivery, and evaluation.

- $\quad$ Provide incentives and rewards for staff who practice these patterns of success.

\section{References}

Ahearn, M., Yee, J. \& Bottum, J. (2003). Regional trends in Extension system resources. Washington, DC: United States Department of Agriculture.

Astroth, K.A. (2005). Leadership in nonformal youth groups: Does style affect youth outcomes? Journal of Extension 34 (6). On-line: http://www.joe.org/joe/1996december/rb2.html.

Avenilla, F., \& Singley, S. (2001). Neighborhood effects on child and adolescent development: Assessing today's knowledge for tomorrow's villages. In A. Booth \& A.C. Crouter (Eds.), (2001). Does it take a village?: Community effects on children, adolescents, and families (pp. 229-243). Mahwah, NJ: Lawrence Erlbaum Associates.

Barber, B.L., Eccles, J.S. \& Stone, M.R. (2001). Whatever happened to the jock, the brain, and the princess: Journal of Adolescent Research, 16 (5), 429-455.

Benson, P.L. (2002). Adolescent development in social and community context: A program of research. In R.M. Lerner, C.S. Taylor, \& A. von Eye. (2002). Pathways to positive development among diverse youth. New Directions for Youth Development. Fall 2002 (pp. 123-147). San Francisco: Jossey-Bass. 
Berkowitz, M.W., \& Bier, M.C. (2004). Research-based character education. In C. Peterson (Ed.), Positive development: Realizing the potential of youth. The Annals of the American Academy of Political and Social Science, Vol. 591 (January 2004) (pp. 72-85). Thousand Oaks, CA: Sage.

Blank, M.J., Johnson, S.D., \& Shah, B.P. (2003). Community as text: Using the community as a resource for learning in community schools. In K.J. Pittman, N. Yohalem, \& J. Tolman (Eds.), When, where, what and how youth learn: Blurring school and community boundaries. New Directions for Youth Development. Spring 2003 (pp. 107-120). San Francisco: Jossey-Bass.

Blyth, D.A., \& Roehlkepartain, E.C. (1993). Healthy communities, healthy youth: How communities contribute to positive youth development. Minneapolis, MN: Search Institute.

Bronfenbrenner, U. (1989). Ecological systems theory. Annals of Child Development, 6, 187-249.

Bronfenbrenner, U. (1994). Ecological model of human development. In T. Husten and T.N. Postlethwaite (Eds.), International Encyclopedia of Education, 2, (pp. 3-27). Oxford, England: Pergammon Press.

Cheshire, T.C. \& Kawamoto, W.T. (2003). Positive Youth Development in Urban American Indian Adolescents. In F.A., Villarruel, D.F., Perkins, L.M., Borden, \& J.G. Keith. (Eds.). Community youth development: Programs, policies, and practices (pp. 79-89). Thousand Oaks, CA: Sage.

Children's Defense Fund. (2000). The state of America's children. Boston, MA: Beacon.

Committee on Community-level Programs for Youth, National Research Council and Institute of Medicine. (2002). In J. Eccles \& J.A. Gootman (Eds.), Community programs to promote youth development. Washington, D.C.: National Academy Press.

Committee on the Future of the Colleges of Agriculture in the Land Grant University System, National Research Council, Board on Agriculture. (1996). Colleges of agriculture at the land grant universities: Public service and policy. Washington, D.C.: National Academy Press.

Connell, J.P., Gambone, M.A., \& Smith, T.J. (2001). Youth development in community settings: Challenges to our field and our approach. In P.J. Benson \& K.J. Pittman. (2001). Trends in youth development: Visions, realities and challenges. Norwell, MA: Kluwer Academic.

Connell, J.P. \& Kubisch, A.C. (2001). Community approaches to improving outcomes for urban children, youth, and families: Current trends and future directions. In A. Booth \& A.C. Crouter (Eds.). Does it take a village?: Community effects on children, adolescents, and families. (pp. 177-201). Mahwah, NJ: Lawrence Erlbaum Associates.

Crosby, G., \& Hamernik, D. (2002). Exploring new opportunities for Extension. Washington, D.C.: Cooperative State Research, Education, and Extension Service. 
Csikszentmihalyi, M., \& Schneider, B. (2000). Becoming adult: How teenagers prepare for the world of work. NY: Basic Books. pp. 289.

Damon, W. (2004). What is positive youth development. In C. Peterson (Ed.), Positive development: Realizing the potential of youth. The Annals of the American Academy of Political and Social Science, 591, 13-24.

Delgado, M. (2002). New frontiers for youth development in the twenty-first century revitalizing \& broadening youth development. New York: Columbia University Press.

Denner, J., \& Griffin, A. (2003). The role of gender in enhancing program strategies for healthy youth development. In F.A. Villarruel, D.F. Perkins, L.M. Borden, \& J.G. Keith. (Eds.). (2003). Community youth development: Programs, policies, and practices (pp. 118-145). Thousand Oaks, CA: Sage.

Dierking, L.D., \& Falk, J.H. (2003). Optimizing out-of-school time: The role of free-choice learning. In Pittman, K.J., N. Yohalem, \& J. Tolman (Eds.), When, where, what and how youth learn: Blurring school and community boundaries (pp.75-88). New Directions for Youth Development, no. 97 Spring 2003. San Francisco: Jossey-Bass.

Eilertson, C., Johnson, K., Martin, R., Minogue, A. \& Tweedie, J. (2003). Before and after school: No time to waste; Programs and providers. Washington, D.C.: National Conference of State Legislatures.

Eldredge, S., Piha, S., \& Levin, J. (2002). Building the San Francisco Beacons. In B. Kirshner, J.L. O'Donoghue, \& M. McLaughlin, (2002). Youth Participation: Improving institutions and communities (pp. 89-108). New Directions for Youth Development, No. 99, Winter 2002. San Francisco: Jossey-Bass.

Flanagan, C., \& Van Horn, B. (2003). Youth civic development: A logical next step in community youth development. In F.A. Villarruel, D.F. Perkins, L.M. Borden, \& J.G. Keith. (Eds.). (2003). Community youth development: Programs, policies, and practices (pp. 273-296). Thousand Oaks, CA: Sage.

Ferrari, T.M. (2003). Working hand in hand: Community youth development and career development. In F.A. Villarruel, D.F. Perkins, L.M. Borden, \& J.G. Keith. (Eds.). (2003). Community youth development: Programs, policies, and practices. (pp. 201-223). Thousand Oaks, CA: Sage.

Ferrari, T.M., \& Sweeney, L.B.H. (2005). Building a collaboration for youth development: The "Club-Within-a-Club." Journal of Extension, 43 (1). On-line: http://www.joe.org/joe/2005february/a4.shtml.

Hamilton, M.A., \& Hamilton, S.F. (2004). Designing work and service for learning. In S.F. Hamilton \& M.A. Hamilton (Eds.). (2004). The youth development handbook: Coming of age in American communities (pp. 147-169). Thousand Oaks, CA: Sage. 
Hobbs, B.B. (1999). Increasing the 4-H participation of youth from high-risk environments. Journal of Extension, 37(4). On-line: http://www.joe.org/joe/1999august/rb1.html.

Huebner, A.J. (2003). Positive youth development: The role of competence. In F.A. Villarruel, D.F., Perkins, L.M. Borden, \& J.G. Keith. (Eds.). (2003). Community youth development: Programs, policies, and practices (pp. 341-357). Thousand Oaks, CA: Sage.

Ingham, P.D. (2005). A snapshot of the change agent states for the diversity project. Journal of Extension, 43 (1). On-line: http://www.joe.org/joe/2005february/a5.shtml.

Irby, M., Pittman, K.J., Tolman, J. (2003). Blurring the lines: Expanding learning opportunities for children and youth. In Pittman, K.J., N. Yohalem, \& J. Tolman (Eds.), When, where, what and how youth learn: Blurring school and community boundaries (pp. 13-27). New Directions for Youth Development, no. 97, Spring 2003. San Francisco: Jossey-Bass.

Johnston-Nicholson, H., Collins, C., \& Holmer, H. (2004). Youth as people: The protective aspects of youth development in after-school settings. In C. Peterson (Ed.), Positive development: Realizing the potential of youth (pp. 55-71). The Annals of the American Academy of Political and Social Science, Vol. 591 (January 2004). Thousand Oaks, CA: Sage.

Kirshner, B., O'Donoghue, J.L., \& McLaughlin, M. (2002). Issue editors' notes. In B. Kirshner, J.L. O'Donoghue, \& M. McLaughlin, (2002). Youth Participation: Improving institutions and communities. New Directions for Youth Development, No. 99, Winter 2002. San Francisco: Jossey-Bass. Pp. 5-7.

MacDonald, G.B., \& Valdivieso, R. (2001). Measuring deficits and assets: How we track youth development now, and how we should track it. In P.J. Benson \& K.J. Pittman. Trends in youth Development: Visions, realities and challenges. Norwell, MA: Kluwer Academic (pp. 155-186).

National Association of State Universities and Land-Grant Colleges (NASULGC) Extension Committee on Organization and Policy. (2002). The Extension system: $A$ vision for the 21st century. On-line: http://www.nasulgc.org/publications/Agriculture/ECOP2002 Vision.pdf.

National 4-H Council. (2004). On-line: http://www.osu/4-H.org

Noam, G.G. (2003). Learning with excitement: Bridging school and after-school worlds and project-based learning. In Pittman, K.J., N. Yohalem, \& J. Tolman (Eds.), When, where, what and how youth learn: Blurring school and community boundaries (pp 121-138). New Directions for Youth Development, No. 97, Spring 2003. San Francisco: Jossey-Bass.

Noam, G.G., Miller, B.M., \& Barry, S. (2002). Youth development and after-school time: Policy and programming in large cities. In B. Kirshner, J.L. O'Donoghue, \& M. McLaughlin, (2002). Youth Participation: Improving institutions and communities (pp. 9-18). New Directions for Youth Development, No. 99, Winter 2002. San Francisco: Jossey-Bass.

Olive, E. (2003). The African American child and positive youth development: A journey from support to sufficiency. In F.A. Villarruel, D.F. Perkins, L.M, Borden, \& J.G. Keith. (Eds.). Community youth development: Programs, policies, and practices (pp. 27-46). Thousand Oaks, CA: Sage. 
Onaga, E., Carolan, M. Maddalena, C., \& Villarruel, F.A. (2003). Positive development for youth with disabilities: Lessons learned from two stories of success. In F.A. Villarruel, D.F. Perkins, L.M. Borden, \& J.G. Keith. (Eds.). (2003). Community youth development: Programs, policies, and practices. Thousand Oaks, CA: Sage. Pp. 162-178.

Pace, K.L. (2003). The character of moral communities: A community youth development approach to enhancing character development. In F.A. Villarruel, D.F. Perkins, L.M. Borden, \& J.G. Keith. (Eds.). (2003). Community youth development: Programs, policies, and practices (pp. 248-272). Thousand Oaks, CA: Sage.

Pancer, S.M., Rose-Krasnor, L., \& Loiselle, L.D. (2002). Youth conferences as a context for engagement. In B. Kirshner, J.L. O'Donoghue, \& M. McLaughlin, (2002). Youth Participation: Improving institutions and communities. New Directions for Youth Development, No. 99, Winter 2002. San Francisco: Jossey-Bass. Pp. 47-64.

Park, N. (2004). The role of subjective well-being in positive youth development. In C. Peterson (Ed.), Positive development: Realizing the potential of youth (pp. 25-39). The Annals of the American Academy of Political and Social Science, Vol. 591 (January 2004). Thousand Oaks, CA: Sage.

Perkins, D.F., \& Borden, L.M. (2003). Key elements of community youth development programs. In F.A. Villarruel, D.F. Perkins, L.M. Borden, \& J.G. Keith. (Eds.). Community youth development: Programs, policies, and practices (pp. 327-340). Thousand Oaks, CA: Sage.

Perkins, D.F., Borden, L.M., Keith, J.G., Hoppe-Rooney, T.L., \& Villarruel, F.A. (2003). Community youth development: Partnership creating a positive world. In F.A. Villarruel, D.F. Perkins, L.M. Borden, \& J.G. Keith. (Eds.). (2003). Community youth development: Programs, policies, and practices. Thousand Oaks, CA: Sage. Pp. 1-23.

QSR NUD•IST (rev. 4). (1997). Software for Qualitative Data Analysis. Thousand Oaks, CA: Sage.

Rasmussen, W.D. (1989). Taking the university to the people: Seventy-five years of Cooperative Extension. Ames, IA: Iowa State University Press.

Ream, G.L., \& Witt P.A. (2004). Organizations serving all ages. In S.F. Hamilton \& M.A. Hamilton (Eds.). (2004). The youth development handbook: Coming of age in American communities. Thousand Oaks, CA: Sage. pp. 51-76.

Rodriguez, M.C., Morrobel, D. \& Villarruel, F.A. (2003). Research realities and a vision of success for Latino youth development. In F.A., Villarruel, D.F., Perkins, L.M., Borden, \& J.G. Keith. (Eds.). Community youth development: Programs, policies, and practices (pp. 4778). Thousand Oaks, CA: Sage.

Roffman, J.G., Suárez-Orozco, C., \& Rhodes, J.E. (2003). Facilitating positive development in immigrant youth: The role of mentors and community organizations. In F.A. Villarruel, D.F. Perkins, L.M. Borden, \& J.G. Keith. (Eds.). (2003). Community youth development: Programs, policies, and practices. Thousand Oaks, CA: Sage. Pp. 90-117. 
Russell, S.T., \& Andrews, N.S. (2003). Adolescent sexuality and positive youth development. In F.A. Villarruel, D.F. Perkins, L.M. Borden, \& J.G. Keith. (Eds.). (2003). Community youth development: Programs, policies, and practices. Thousand Oaks, CA: Sage. Pp. 146-161.

Scheele, S. (1975). Reality construction as a product of Delphi interaction. In H.A. Linstone, \& m. Turoff (Eds.), The Delphi method: Techniques and applications (pp. 37-71). Reading, MA: Addison-Wesley.

Schiamberg, L.B., Paulson, S., \& Zawacki, K. (1998). An ecological perspective for teaching about the adolescent. In J.P. McKinney, L.B. Schiamberg, \& L.G. Shelton (Eds.), Teaching about adolescence: An ecological approach. New York: Garland Publishing. Pp. 15-38.

Sherman, R. (2002). Building young people's public lives: One foundation's strategy. In B. Kirshner, J.L. O'Donoghue, \& M. McLaughlin, (2002). Youth Participation: Improving institutions and communities. New Directions for Youth Development, No. 99, Winter 2002. San Francisco: Jossey-Bass. Pp. 65-82.

Steinberg, A., Almeida, C., \& Allen, L. (2003). Multiple pathways to adulthood: Expanding the learning options for urban youth. In Pittman, K.J., N. Yohalem, \& J. Tolman (Eds.), When, where, what and how youth learn: Blurring school and community boundaries (pp. 29-44). New Directions for Youth Development, No. 97, Spring 2003. San Francisco: Jossey-Bass.

The Future of Children Report. (2000). After-school programs: Issues and ideas. The Future of Children, November, 2000.

Urban Task Force. (2003). Urban extension: A national agenda. Washington, D.C.: The United States Department of Agriculture. On-line: http://www.reeusda.gov/ecs/urbanet.htm.

Wynn, J.R. (2003). High school after school: Creating pathways to the future for adolescents. In Pittman, K.J., N. Yohalem, \& J. Tolman (Eds.), When, where, what and how youth learn: Blurring school and community boundaries. New Directions for Youth Development, No. 97, Spring 2003. San Francisco: Jossey-Bass. pp. 59-88.

Yohalem, N. (2003). Adults who make a difference. In F.A. Villarruel, D.F. Perkins, L.M. Borden, \& J.G. Keith. (Eds.). Community youth development: Programs, policies, and practices (pp. 358372). Thousand Oaks, CA: Sage.

Zoomerang. (1999-2002). Market Tools Inc. On-line:

http://www.zoomerang.com/join/member-subscriber.zgi?pid=.

(C) Copyright of Journal of Youth Development Bridging Research and Practice. Content may not be copied or emailed to multiple sites or posted to a listserv without copyright holder's express written permission. Contact Editor at: patricia.dawson@oregonstate.edu for details. However, users may print, download or email articles for individual use.

ISSN 2325-4009 (Print); ISSN 2325-4017 (Online) 